\title{
THE VIOLATION OF MAXIM RULES IN KETOPRAK HUMOR
}

\author{
Muh Imam Shofwan \\ Madrasah Tsanawiyyah NU Banat, Kudus, Indonesia
}

\begin{abstract}
The investigation in fact aimed mainly to analyze the theory of conversational implicature proposed by Austin and later on extended by grice's principle maxim which can be universal and applied to all languages of the world, including java language art show of ketoprak entitled "joko kendil". The study is expected to be beneficial to the world of literature. In addition, the writer hopes that the result of the study will also give additional information to the reader and contribute to the development of literary study particularly among students who are interested in the literary study. Twenty-three minutes recorded video conversation of all participants of the show data were transcribed into written form and translated into English. Needless to say, the analysis of the data has been based on both ustin's and grice's principles of pragmatics, conversational implicature theory. Illustrative examples for flouting the four maxims of speech were introduced and analyzed pragmatically. Particularly the research was objected to find out the violation of maxims of quantity, quality, manner and relation flouted and an implicature from each generated. From the analysis, it was found that the claim of "ketoprak" speech can be systematized and it has implicatures in one way but not in another is to some extent true. Thus, this theory can be applied to other java language idiolects.
\end{abstract}

\section{INTRODUCTION}

In our daily life, we communicate with other and simply understand each other without thinking in the way how we do understand each other. In communicating, we explore the meaning through or use the sentence. However, sometimes in exploring the meaning we should not express explicitly, because at the same time we should consider the interlocutors, situations, and also the effect of what we said. So, we finally should explore the meaning implicitly. As Banga et al in Moha. (2009, p. 1) said that "In everyday conversation, sentence meanings are not always expressed explicitly, but can also be merely implied". It is like investigation behind what the speaker says and is called implicature by Grice (1975). It is not study of what is said but the meaning of what is said. In some event, implicature can be used by the speaker to keep politeness and to avoid displeasure.

Grice's Conversational Implicature theory is one of the most important contents of Pragmatics that relate to the investigation of the message conveyance. The theory focuses its attention on the phenomenon of conveying more than what is said. Grice (1975, p. 44) clarified implicature in two categories, conventional and conversational. Conventional implicature is largely generated by the standing meaning of certain linguistic expressions, such as "but" and "moreover". Therefore, it can be said conventional implicature of an expression are part of its semantics. While conversational implicatures depend on features of the conversational situation or context and not just on the conventional meanings of 
the words used. Therefore, the notion of a conversational implicature is a pragmatic notion.

In this case, this research will be focus on the conversational implicature. Grice (1975) uses the term implicature to account for what a speaker can imply, suggest or mean as distinct from what the speaker literary says. By far, conversational implicature is subsumed to mean an implication or suggestion deduced from the point of an utterance. A conversational implicature uses the cooperative principle, which governs the efficient use of conversation. For instance, if someone says "look, the train!" while approaching a railway station, the implicature is "we must be hurry".

In a conversation, the speaker may do one of four things with regards to the cooperative principle and the maxims. The speaker may observe the maxim. This is the default assumption. The speaker may opt out of a maxim by using a phrase that eliminates or mitigates the effect of the maxims and signals this to the addressee. This is called a hedge. The speaker may flout a maxim to the full knowledge of the addressee.

When we watch and listen to an art show on the stage or TV program, we also strictly understand and even involve our emotion in the story of the show. In addition, between the participants of the play, they merely understand and able to deliver the idea and pass the messages in the role play easily. The communications that goes between the participants in art show sometimes conveys information that goes beyond what they strictly say. There are exaggeration and irony message conveyance.

Ketoprak (Javanese: Kethoprak) is one of the art shows played on the stage. It is a theatrical genre of Java featuring actors who may also sing to the accompaniment of the gamelan. It draws its stories from Javanese history and romances. The ketoprak that took the story of ancient Java is quite similar with Wayang wong performance, however ketoprak performance is more free for improvisations, jokes and adoption of popular languages, while Wayang wong are traditionally highly stylized with precise and structured dance drama discipline. In their performance, the actors usually imply, suggest or mean as distinct from what the speaker literary says.

Based on those phenomena, the writer wants to analyze the illustrative examples for flouting the four maxims of speech introduced by Grice. That is, it was explained in detail how the maxims of quantity, quality, manner and relation were flouted and an implicature from each was generated.

\section{THEORETICAL FRAMEWORK}

Cooperative principle is the most important thing in pragmatic to analyze either violation or flouting of maxim rules that is happened in Ketoprak Humor entitled Joko Kendil. The cooperative principle can be divided into four maxims, called the Gricean maxims, describing specific rational principles observed by people who obey the cooperative principle; these principles enable effective communication. Grice proposed four conversational maxims that arise from the pragmatics of natural language. The Grice's Maxims are a way to explain the link 
between utterances and what is understood from them because some characters said things that are not appropriate with what maxim rules stated to become the perfect existence of implicature so that the hearer will understand fully what the speaker implies through conversation and their statements. Also, maxim rules by Grice are needed for analyzing what is behind the text and if there is any failure in understanding the conversation. By using one by one maxim rules, violating and flouting maxim can be found and what is wrong about the implicature. There are 4 maxim rules that are stated by Grice:

Grice sums up the Cooperative Principle into four conventional maxims namely, relevance (relation), quality, quantity and manner.

1. Relevance: Be Relevant

This means that in every conversational situation the speaker/hearer should adhere to the topic of their conversation. They must always ensure that they give only information that is related to the conversation and in their interaction with each other. Grice illustrates as follows:

... if I am mixing ingredients for a cake, I do not expect to be handed a good book, even cloth...

The implication here is that 'book' and 'cloth' are irrelevant in the context. So, in communication, it is unnecessary to include issues not related to the topic under consideration. Avoid padding and circumlocutions.

\section{Quality}

This maxim calls for honesty and sincerity on the part of participants in a discourse. They should not say or give information which they believe is false or which they do not have adequate evidence or are not sure of. In other words, they should try to make their contributions truthful. In fact, the maxim of quality has some form of moral tone attached to it.

Grice speaking about this maxim says, I expect your contribution to be genuine and not spurious. If I need sugar as an ingredient in the cake you are assisting me to make, I do not expect you to hand me salt...

3. Quantity

The maxim means every speaker should be informative in a discourse by saying the right amount of what is required. A speaker should not say more or less than what is necessary for the moment. Verbosity and redundancy weakens the interest of the listener and makes the reader confused. However, being brief does not entail leaving out vital points as this will affect the hearer's or reader's understanding.

Grice puts it as follows: If you are assisting me to mend a car, I expect your contribution to be neither more nor less than is required; if for example, at a particular stage I need four screws, I expect you to hand me four rather than two or six. 
Leech (1983) supports this by quoting O' Hair as follows:

Unless there are outweighing good reasons to the contrary, one should not make a weaker statement rather than a stronger one if the audience is interested in the extra information that would be conveyed by the latter.

\section{Manner}

Grice uses it to mean participants in a discourse should not make their contributions obscure, ambiguous or difficult to understand. It is a call for parties in any communication discourse to be perspicuous (clear). Besides, they should be very brief and organized. High sounding and jaw breaking as well as complex words and phrases should be avoided because the essence of communication is that the hearer should be able to understand. A speaker should not use words for self-aggrandizement or to earn cheap praise. Furthermore, the maxim requires politeness (treat your listeners as you would like to be treated).

Mey (2001) sums up the four maxims in these words: Make your contribution such as is required, at the stage at which it occurs, by the accepted purpose of the talk exchange in which you are engaged.

\section{RESEARCH METHOD}

In doing this research, the researcher uses descriptive qualitative method. Data source are taken from two scenes of Ketoprak humor video show taken from YouTube. Its data was called corpus. Corpus is a selection of linguistic data which is written and spoken. According to Adolps, (2008, p 11), "corpus is dedicated to the selection and groupings of texts, spoken and written, that make up any one corpus". In collecting the data, the researcher watched the movie in several times and made the transcription of the movie. The data in Javanese language were then translated into English. The researcher analyzed the data by separating the character's utterances which flout toward Grice's maxim and describe the background context which indicate the choice of flouting. In analyzing the data, the writer also uses intuitive knowledge to decide the flouting maxims uttered by the characters in the show.

\section{Technique of Analyzing Data}

Since the data were in the form of qualitative data, this study utilized the following methods in analyzing the data, i.e. transcribing, identifying, classifying, and interpreting.

1. Transcribing deals with the process of transcribing the sound data from the ketoprak art show. In this process, the researcher transcribed himself the recording data (video data) into written text by listening to the audio data, and writing it down.

2. Identifying deals with to identify the flouting maxim made by the participants.

3. Classifying the data based on the Grice's maxim.

4. Interpreting phase, this is the last phase in which the researcher interprets the data. 


\section{FINDING AND DISCUSSION}

\section{Findings}

The findings of this current research were used to answer the research questions in regard to the violation of maxim rules by all ketoprak humor participants. The violation of the participants of all maxims can be observed of the following examples:

(1): (source in Java)

Widyowati : panjenengan ki menuso tho?

Joko Kendil : kwe ora usah wedi karo aku. Aku ki yo, ki yo podo karo kwe. Mung modele dewe ngono ae. Aku biasa kok, aku yo sering nelpon wong kok. (chuckle)

Widyowati : you human being, aren't you?

Joko Kendil : don't worry. I am just human being like you. Just, I look different. I am ordinary man. I usually also call someone by phone.

According to Grice's theory of Conversational Implicature mainly nonobservance of the maxim case, an implicature is generated only in the case of flouting the maxim. Basically, a maxim is flouted when a speaker fails to observe the maxim blatantly and of course with no intention to mislead or deceive the hearer. Additionally, Grice introduced four types of flouting a maxim: Quantity, Quality, Relation and Manner. The example (1) is an example where the maxim of quantity has been flouted. The maxim of quantity is flouted when a speaker gives either more or less information than it is required. Needless to say, this happens blatantly and an implicature is generated. However, we can notice that the first speaker (widyawati (W) ) has asked the second speaker (Joko kendil (JK)) about him (is he human being), however JK provided more information than the situation demands. He answered the question which is not asked in W's question. The choice of the quantity flouting in this context, for JK wanted to explain his existence as human being.

\section{(2): (source in Java)}

Joko Kendil : aku nek ngeti kwe koyo ngono ki kok gandul gandul piye kwe kok abot, sopo jenengmu, spo cah ayu?

Widyowati : Manuso tenen tho?

Joko Kendil : tenan

Widyowati : nek ngapusi piye?

Joko Kedil : lho karek yo kono.

Joko Kendil : when I see you hanging up, it seems so heavy. What is your name beautiful girl?

Widyowati : are you really human?

Joko Kendil : sure

Widyawati : you are not lying, aren't you?

Joko Kendil : up to you 
In the second example, it was how the maxim relevance was being flouted by the participant. This means that in this conversational situation, the hearer did not adhere to the topic of their conversation. She gave information that was not related to the conversation and even she tried to move to another topic by committing a question. In this situation the JK would like to seduce $\mathrm{W}$ by performing some joking, but $\mathrm{W}$ did not want to respond his joking and tried to escape by asking another topic. This implies that she wanted to avoid of making joke with him which discussed about a taboo topic.

The flouting of relevance maxim can also be seen from the following dialogue:

Joko Kendil : Aku topo, kepingin roh sejatine sopo aku, kepingin roh wong urip ki kudune kaweruh aku.

Servant : Pungkasane?

Joko Kendil : oleh ilmu bumi (relation, qualitative, quantitative)

Joko Kendil : I am in asceticism, because I really want to know who I am. I want to know how people truly live.

Servant : and the result?

Joko Kendil : I got geology knowledge.

The sentence 'I got geology knowledge' indicates that JK respond to servant's question with irrelevant topic discussion where they previously talk about living as asceticism and the result of living alone in the forest. This implies that JK did not want to answer the servant's question and wanted to stop the conversation, because he was not patient to meet his mom to tell that he wanted to get marry my a princes from the kingdom.

(4): (source in Java)

Joko Kendil : tenan kenalan? Ora opo opo ora loro kok

Widyowati : di tepungake ae yo kisanak? Jenengku wdyowati, jeneng mu sopo?

Joko Kendil : tepungke karo aku yo, aku edi kendil, (qualitative)

Widyowati : Edi kendil ki piye tho? Seng setengah modern, seng setengah kuno.

Joko Kendil : are you sure, that you want to know me? It is ok, I won't hurt.

Widyowati : ok, let me introduce, my name is widyowati.

Joko Kendil : please, let me introduce myself. I am Edi Kendil (chuckle)

Widyowati : how can be Edy Kendil. A half is modern and the other is ancient

This third dialogue is the example of flouting of quality maxim. This maxim calls for honesty and sincerity on the part of participants in a discourse. They should not say or give information which they believe is false or which they do not have adequate evidence or are not sure of. In the dialogue three, $\mathrm{W}$ introduced herself in hope she would get the same true answer from JK introduction. On the 
contrary, JK gave wrong answer by stating wrong name. He implied that by performing another joking, he would get more attention from $\mathrm{W}$. and the result, he got more attention from her and being accepted by explaining his joking of introducing wrong name.

Another implicature which flouts quality maxim can also be seen from the following example:

(5): (source in Java)

Widyowati : ora, lucu ok iki. Iki opo iki (sambil mengelus perut Joko)?

Joko Kendil : iki aku ndarbeni telung wulan ngono.

Widyowati : wong priyo kok iso ndarbeni.

Widyowati : no, it is not funny. What is this? (by pointing to JK stomach)

Joko Kendil : this one? I am pregnant

Widyowati : you are a man, how can you be pregnant.

By stating the sentence that he was pregnant, JK would like imply that he wanted to show his weaknesses of having ugly face and in proportional body shape. There, he flouted of maxim quality by performing chuckle and giving dishonest answer.

(6): (source in Java)

Mbah kakung : kabeh sak omah ki nggolek'i kwe. Kwe ora ono neng omah, kabeh do bingung. Joko-joko

Mbah putri : ngopo tho nangis?

Mbah kakung: Wong putu siji bagus koyo ngene, dadio mati yo mati yo. Katimbang nyusahke

Joko kendil : Iki twek tpi malah keparat ngono lho.

Mbah putri : mbah ngundang putu yo ojo ngono. Putu mung siji kok.

Mbah kakung : joko-joko dumpil

Mbah putri : dumpal dumpil

Mbah kakung : sopo seng muni dumpil. Joko kenthir. Lha seng njenengke ra aku dewe tho yo?

Mbah puti : iyo kwe dewe

Mbah kakung : lha kok aku lali?

Mbah kakung : everyone was looking for you. You were not at home, everyone was confused, Joko, Joko.

Mbah putri : why are you crying?

Mbah kakung : the only my handsome grandson, if you want to die, just die. Don't ever make anyone confused.

Joko kendil : This old man is demanding.

Mbah putri : Grand pa, please don't call your grandson such that name. He is the only one

Mbah kakung : Joko-Joko Dumpil 
Mbah putri : Dumpal-dumpil

Mbah kakung : who say dumpil?Joko Kenthir

Mbah putri : yes, yourself

Mbah kakung : how can I forget?

Having introduced three types of flouting the maxim: Quantity, Quality and relation or relevance, I now proved that Ketoprak humor also floats the fourth type (principle), flouting the maxim of Manner. Fundamentally, a maxim of manner is flouted when a speaker is being disorderly, vague, ambiguous, or wordy in his or her reply to the other party (ies). Once again, and just as it has been mentioned above this happens purposefully and the result is a generated implicature or an additional meaning rather than the communicated meaning.

Example (6), however, illustrates how the speaker (Mbah kakung (MK) has flouted the maxim of manner. Mainly, this utterance implies that he would like to show his love to his only grandson, Joko Kendil. However, he showed his love by performing a joke by saying" the only my handsome grandson, if you want to die, just die". Don't ever make anyone confused. This utterance shows that the grandpa float maxim manner by being disorderly, vague, ambiguous toward his utterance. Moreover, between the participants finally flow and respond to the joking by stating the same flouting manner. This can be seen from the respond" this old man is demanding".

Another example about flouting the maxim of manner is example (7).

Example (7): (source in Java)

Mbah putri : kwe kok seneng neng alas lapo?

Joko Kendil : ayem ora ono seng nggolek'i

Mbah Putri : yo ora, dadine kwe kumpul karo konco-koncomu tho? Ketek, munyuk, codot

Joko Kedil : lha ngerti koyo ngono lapo di gole'i?

Mbah putri : why do you like living in the forest?

Joko Kendil : I am happy, and nobody looks for me

Mbah Putri : oh no. you can gather with your friend, can't you? Monkey, orangutan and bat, aren't they?

Joko Kedil : lha ngerti koyo ngono lapo di gole'i?

The grandma statement "oh no. you can gather with your friend, can't you? Monkey, orangutan and bat, aren't they?" did not have intention to underestimate JK that he is better with animal in the forest, but she teaches him a good value in order not to leave his mom and lives in the forest. However, she implies her true message and also emphasizes it by flouting maxim manner.

\section{CONCLUSION}

The conclusion concerning to the research problems can be drawn. Based on the analysis above, it can be concluded that the interaction carried out in Ketoprak Humor entitled Joko Kendil performance implies some implicatures and also flouts all maxim principles as proposed by Grice, namely maxims quality, quantity, relevance and manner. Moreover, the flouting maxims by all characters 
in ketoprak Humor deal with creating some jokes to attract the viewers and listeners. Even though the characters implied some implicature in their performances and broke some cooperative principle, each participant understood each other and able to deliver the message well. Therefore, it can be concluded that the claim of "Ketoprak" speech can be systematized and it has implicatures in one way but not in another is to some extent true. Thus, this theory can be applied to other Javanese language idiolects.

\section{REFERENCES}

Levinson, S. C. 2000. Pragmatics. London: Cambridge University Press.

Leech, G. 1983. The Principles of Pragmatics. London: Lowmans GroupLimited. https://www.youtube.com/watch?v=BluV5o3uj_8 (4/28/2016) 06:08 pm

Lyons, J. 1968. Introduction To Theoretical Linguistics. Cambridge University Press

Mey, J. L. 1993. Pragmatics: An Introduction. Oxford: Blackwell.

Robert M. H. 1991. Logical Form and Implicature. In Steven Davis, editor, Pragmatics: A Reader, pages 316-364. Oxford: Oxford University Press.

Yule, G. 1996. Pragmatics. New York: Oxford University Press.

Black, E. (2006). Pragmatic Stylistics. Edinburgh: Edinburgh University Press Ltd.

Leech, G. (1974). Semantics . Penguin: Penguin Books.

Alduai, S. Conversational Implicature (Flouting the Maxims). Journal of Sociological Research

Tsojon, I. Y., \& Jonah, P. K. 1975. An Analysis of the Pragmatic Implicatures of Selected Advert Billboards around Jos Metropolis in Terms of Grice. International Journal of English Language Teaching.

Wang, H. (2011). Conversational Implicature in English Listening

Comprehension. Journal of Language Teaching and Research Journal of Language Teaching and Research. 
